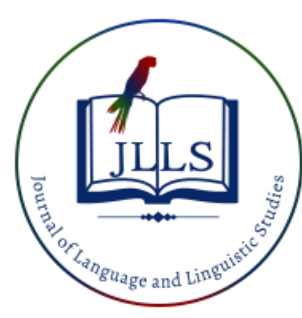

Available online at www.jlls.org

JOURNAL OF LANGUAGE AND LINGUISTIC STUDIES

ISSN: $1305-578 \mathrm{X}$

Journal of Language and Linguistic Studies, 16(3), 1402-1414; 2020

\title{
Language preparatory school students' use of modern technologies to study English
}

\author{
Başak Ercan ${ }^{\text {a } 1}$ iD \\ APA Citation: \\ ${ }^{a}$ Akdeniz University, Antalya, Turkey
}

Ercan, B. (2020). Language preparatory school students' use of modern technologies to study English Journal of Language and Linguistic Studies, 16(3), 1402-1414.

Submission Date:26/05/2020

Acceptance Date:21/07/2020

\begin{abstract}
Providing language students with creative and effective language learning environments so that they can gain communicative competence is of great importance. Therefore, integration of technology into language learning has become much more valuable where the target language is taught as a foreign language, allowing learners to expose themselves more to the target language and it helps create natural environments for language learning. It is clear that today's young learners are really keen on using technology. However, there is an argument going out about if there is a change in methods of teaching and learning a foreign language in terms of satisfying the needs of these "digital natives" and there is not much information about this issue at tertiary level language teaching and learning in Turkish context. Thus, the aim of this study is to address this gap and find out the most efficient and / or popular technologies used by learners to promote the development of language skills. Having this aim in mind, a small scale research was carried out among English language prep school students at a state university in Turkey. The results indicated that using modern technologies to study English is not very popular among the students and they are not aware of most of the strategies they can use. Another significant result is that the students need guiding to integrate ICT in their studies. Therefore, teachers themselves have to have the required skills to work with modern technologies to integrate ICT more into education settings.
\end{abstract}

(C) 2020 JLLS and the Authors - Published by JLLS.

Keywords: use of technologies; development of language skills; language learning environments

\section{Introduction}

The latest advancements in modern technologies have led to changes in the settings of education environments. Computer-assisted tools, Internet and other modern technologies have reshaped the traditional classrooms, turning them into modern, up-to-date learning environments where new methods, techniques and strategies of teaching and learning can take place. Information and communication technologies are of great importance for the development of the countries in today's globally networked environment. It is considered that widespread Internet access is valid for nations to get a place in global education (Helsper et al., 2009). In other words, technology has a very important place in education

\footnotetext{
${ }^{1}$ Corresponding author. Tel::

E-mail address: basakercan@akdeniz.edu.tr
} 
settings and learning process should be redesigned and managed accordingly so as to create efficient and productive learning environments (Sarıçoban, Tosuncuoğlu \& Kırmızı, 2019). As Lunenburg and Orstein (2004) point out new technologies transfer teaching and learning (1) from whole group instruction to individualized instruction, (2) from one-size / one-paced instruction to customized / selfpaced instruction, (3) from passive learning to active learning, (4) from absorbing facts from teachers and textbooks to navigating the information highway and World Wide Web, and (5) from the teacher as a transmitter to the teacher as a facilitator. It seems that, when applied, modern technologies have made the educational activities much easier to a great extent (Brown \&Warschauer, 2006).

Current higher education learners are accepted as "digital natives" (Prensky, 2001) or "Net generation" (Tapscott, 1998) since they have been familiar with the presence of computers and the Internet and all other types of Information and Communication Technologies (ICT) in their lives and have become "native speakers" of these digital era especially in most developed countries and they use technology-mediated tools for entertainment and academic study. Therefore, these $21^{\text {st }}$ century students called as "digital natives" or "Net generation" with their changing attitudes and values even need more of a student-centered learning environment, where skills such as creative thinking, problem-solving, collaboration and reflection are being brought into the centre. In that sense, use of modern technologies is a leading actor to create such environments as a bridge from instruction to construction and discovery (Tapscott, 1999), supporting more meaningful and active learning (Elmas \& Geban, 2012).

Web 2.0 covers a range of technologies, services and trends underpinned by the growth of a critical mass of internet use. "It is about the using the Internet as a platform for simple, lightweight services that leverage social interactions for communication, collaboration, and creating, remixing and sharing content" (Crook \& Harrison, 2008, p.5). Researches show that learners use technology for different reasons and they fall into mainly three categories (Luckin et al., 2009):

1- Researchers: readers having not much critical enquiry or analytical awareness

2- Collaborators: those sharing files, gamers and communicators having not much the sense of collaborative knowledge construction;

3- Producers and publishers: those sharing experience via social networking sites; and having some co-publication and production with input from teachers.

Kenneddy et al. (2010)'s research reveals for another classification consisting of four types of student technology users:1. Power users: those using a wide range of modern technologies very often, 2. Ordinary users: those using standard Web and mobile technologies regularly, 3. Irregular users: being alike as ordinary users but engaging in most of the technology-based activities less often, and 4. Basic users: using new and emerging technologies extremely less often and using standard Web technologies less than weekly or monthly and using standard mobile features on a regular base.

Taking the needs of this new generation into consideration, it is further argued that the knowledge content and the methods and techniques shaping lessons contents in universities have to be redesigned (Lee et al., 2014). However, there is another side of the medallion. Some researches show that learners use the Internet for their academic work but they do not think that the Internet has a positive influence on their ability to learn and their generation is not as good at learning as pre-ICT generation, stating that school is not adjusted to today's world (Ben-David Kolikant, 2009, 2010). Ben-David Kolikant (2010) claims that this finding implies that "the students' perceived self-efficacy in this respect is relatively low, which means that learners need more guidance for embedding ICT into their academic studies. In another study by Kvavik (2005), only a minority of the learners stated that the most valuable benefit of information technology use in class is improved learning. In a study carried out by Ben-David Kolikant (2009), all student participants stated that they used the Internet for school work but a majority of them did not think that the Internet has a positive influence on their ability to learn; specifically, they disagreed 
with the statement "I believe my generation knows how to learn better than the generation that did not have computers." Ben-David Kolikant (2010)'s forward study aligns with his previous one concerning this respect and according to the one fifth of the participants, the reason why they are not as good learners as previous generation is because school is not adjusted to today's world while two thirds of them think that the reason why they are worse learners is because they are lazy due to the use of the Internet; they do not read enough. However, language learning environments differ from other learning environments in terms of using modern technologies because they are great tools to provide foreign language learners with authentic material, appealing them in social, cognitive and personal level (Misir, 2018) in that these learners do not have much chance to be exposed to the target language outside the walls of the classroom. Concerning this, it is important for foreign language learners to embed technologies into their daily language study outside the classroom as well and there is not much study concerning this issue in Turkish context.

Therefore, it caught the interest of the author and she thought it is important to clear out for what purposes and how often modern technologies are used by language prep school students at a state university. In Turkey, language prep schools in state higher education institutions usually have a lowtech language learning environments having only one computer in each class for the instructor use with a projector and the Internet access, which is also valid for the students on campus; yet, outside class, students have less interaction with modern technologies facilitated by the university so as to study English.

This study is interested in better seeing whether language students use the Internet and technologymediated tools inside and especially outside the language learning environments by investigating learners' purpose and frequency of using these tools in their lives. Therefore, it contributes to our understanding on how and for what purposes language learners at a prep school at tertiary level use technology, to what extent technology-mediated tools are preferred by them in language learning process and what factors lead learners to refrain from technology use to learn a foreign language in Turkish context, on the one hand; it also helps better understand possible areas of support both educators and learners need so as to enhance the use of technology-mediated tools in language teaching and learning process, on the other.

\subsection{Literature review}

Researchers have debated second / foreign language learning for years by using theoretical models such as Behaviorist, Innatist and Interactionist to better grip the concepts of first language acquisition and second / foreign language learning (Nor \& Rashid, 2018).

Although there are different approaches, no single one is seen as the best approach and the scholars agreed on the idea that an eclectic approach has to be followed in order to satisfy different learner needs. Meanwhile, learning settings have shifted from teacher-centered to student-centered learning environments and today's effective language learning is based on communicative competence, which puts forwards that foreign language lessons should consist of a wide variety of opportunities for students to communicate in the target language since students learn through interaction (Bailey, 2005), marking the importance of modern technologies in that providing learners with authentic materials and helping them better understand the culture of the target language they are learning.

As Harmer (2007) points out, sufficient language exposure undoubtedly leads to successful language learning where the necessity of using modern technologies emerge in today's digital age, providing learners with an immense source of authentic materials. There are two functions of ICT in learning languages: More passive behaviors such as reading and listening are associated with learning from ICT, 
while more active behaviors such as creating, writing and updating are associated with learning with ICT (Harris \& Rea, 2009 cited in Tay, Lim, Lim \& Koh, 2012).

Modern information technologies use also helps students engage in self-regulating their language learning outside the borders of the classroom, not only providing them with a vast variety of exercises but also flourishing their communicative competence, by allowing them to communicate both in a synchronous way (videoconferencing, Skype) and in an asynchronous way (forums, chats, blogs, etc.) (Shishkovskaya et al., 2015), thereby through these modern technologies, EFL learners have access to plenty of sources, involving all four language skills and grammar, vocabulary and pronunciation exercises. Most importantly, learners have the chance to get a lot of authentic materials, which is of crucial importance where English is taught as a foreign language rather than as a second language.

There is no doubt that current global developments have opened up more opportunities for educationists to design and implement ICT-based lessons (Rahamat et al., 2017) and several studies proved that ICT use in language learning increased the motivation of the learners, resulting in better learner outcomes (Banditvilai, 2016; Wang et al., 2015; Nachoua, 2012), made language learning easier and students seem to like to see more technology use in language classrooms (Lee et al., 2014). These adapted learning methods in current teaching and learning environments also enhance the potential of self-directed learning among students of EFL (Zainuddin \& Perera, 2018).

\subsection{Research questions}

The aim of this study is to find out the strategies related to modern technologies used by the English intensive program students to promote their language learning. To reach this aim, the following research questions were specified:

1. How much time do students spend on the Internet a day?

2. What do they use the Internet for?

3. How many hours a day do they spend studying English using ICT?

4. In which way do the students use ICT to study / learn English?

5. What are the factors preventing them studying English using ICT?

\section{Method}

\subsection{Research design}

In order to find out the information and communication technologies use of English prep school students to study English, the researcher preferred a quantitative analysis. A questionnaire developed by the researcher after an in-depth literature survey about ICT use in language classes was applied in order to provide an objective view of the students. For this purpose in mind prep school students were applied the questionnaire after informing them about the purpose of the research.

The research was conducted in a school of foreign languages, which offers one year intensive English at a large state university in Turkey. Each class is equipped with a computer and projector with Internet connection. The course books used had also a digital tool to be used in classes and all the teachers used it during lessons and a learning management system; yet, this learning management system was not used effectively outside the classroom. Problems caused by poor Internet connection from time to time were said to occur and there was also a technical support when needed. Teachers were not given special training and/or support about how to integrate technology into lessons. 


\subsection{Sample / Participants}

Compulsory English language students (in a total of twenty-five classes) registered at a preparatory school of a state university constitute the universe of this study. Instead of reaching the whole universe, it was decided to study with a good representative sample and thus out of these 25 classes, five of them were included in the study. As a result, these English language classes were numbered from 1 to 25 and five of them were taken into the sample. In this study where systematic sampling method was used, number 3 was selected as a result of casting lots (Bellhouse, 2014) and then with the order of sequence numbers, the classes numbered 3, 8, 13, 18 and 23 were included in the study.

As a result, 142 students (female 56, 39.44\%; male, 86; 80.56\%) who were studying English at an intensive English program at a state university in Turkey constituted the sample of this current research. $95(66.90 \%)$ of the students had a computer, laptop or a tablet of their own and the rest $47(33,10 \%)$ of them had a shared one. The students, coming from different regions of Turkey, were prospective engineering, tourism and gerontology students.

\subsection{Data collection tool and analysis}

The data collecting tool in the scope of this study aiming at finding out how often and for what purposes English language students use modern technologies to study English was formed as a questionnaire. Since there are different types of questions in a questionnaire, a total score is not calculated and only the frequencies and percentages related to the question are reported (Aiken, 1997), and since it is aimed at calculating how often more than one feature is repeated rather than measuring a psychological feature, validation and reliability analyses are not required (Balaban, 2014) in this current study.

In the first part of the questionnaire, the students were asked about their personal information concerning their gender, whether they have a computer / laptop / tablet and then their habits related to ICT use for their everyday life and studying English. Lastly, they were questioned about the barriers which hindering them from ICT use to study English. The gathered data was coded and analyzed via SPSS 22 package program for social sciences. Descriptive statistics were used to analyze the data and the results were shown in tables

\section{Results}

In the scope of this current study, the results of frequency analysis concerning the $1^{\text {st }}$ research question 'How much time do students spend on the Internet a day?' are shown in Table 1.

Table 1. Time spent on the Internet a day

\begin{tabular}{lcccc}
\hline & Frequency & Percent & Valid Percent & Cumulative Percent \\
\hline 1-2 hours & 16 & 11.30 & 11.30 & 11.30 \\
2-3 hours & 13 & 9.20 & 9.20 & 20.40 \\
3-4 hours & 37 & 26.10 & 26.10 & 46.50 \\
4-5 hours & 37 & 26.10 & 26.10 & 72.50 \\
More than five hours & 39 & 27.50 & 27.50 & 100.0 \\
Total & 142 & 100.0 & 100.0 & \\
\hline
\end{tabular}


When Table 1 examined, it is seen that $26,10 \%, 26,10 \%$ and $27,50 \%$ of the students spend $3-4$ hours, 4-5 hours and more than 5 hours on the Internet a day respectively, which means that nearly $80 \%$ of the students spend at least three hours on the Internet a day. This finding is not surprising concerning the digital era we live in.

As to the $2^{\text {nd }}$ research question, Table 2 reveals for what purposes English prep school students use the Internet and they are classified under eight titles, which are entertainment, to socialize and keep in touch, to follow the current events, to get information, to study / learn English, to study / learn subjects other than English, to shop online and other(s).

Table 2. Purposes for Internet Use

\begin{tabular}{|c|c|c|c|}
\hline & Purposes & Frequency & Percent \\
\hline \multirow{8}{*}{$\begin{array}{l}\text { The purpose of } \\
\text { using Internet }\end{array}$} & For entertainment & 98 & $\% 69.00$ \\
\hline & To socialize and keep in touch & 96 & $\% 67.60$ \\
\hline & To follow the current events & 32 & $\% 22.50$ \\
\hline & To get information & 83 & $\% 58.50$ \\
\hline & To study/learn English & 60 & $\% 42.30$ \\
\hline & To study / learn subjects other than English & 16 & $\% 11.30$ \\
\hline & To shop online & 52 & $\% 36.60$ \\
\hline & Other(s) & 1 & $\% 0.70$ \\
\hline
\end{tabular}

Entertainment (69\%), to socialize and keep in touch $(67,6 \%)$ and to get information $(67,6 \%)$ rank the top three purposes of using the Internet with high percentages. The use of Internet for the purpose of to study / learn English falls behind these with 42, 30\%.

Concerning the $3^{\text {rd }}$ research question, 'How many hours do you use ICT to study English?", the results are shown in Table 3 .

Table 3. Time spent studying English using ICT

\begin{tabular}{lcccc}
\hline & Frequency & Percent & Valid Percent & CumulativePercent \\
\hline None & 20 & 14.10 & 14.10 & 14.10 \\
Less than an hour & 60 & 42.30 & 42.30 & 56.40 \\
1-2 hours & 40 & 28.20 & 28.20 & 84.60 \\
2-3 hours & 11 & 7.80 & 7.80 & 92.40 \\
3-4 hours & 3 & 2.10 & 2.10 & 94.50 \\
4-5 hours & 7 & 4.90 & 4.90 & 99.30 \\
More than five hours & 1 & 0.70 & 0.70 & 100.0 \\
Total & 142 & 100.0 & 100.0 & \\
\hline
\end{tabular}

$14,10 \%$ of the students never use ICT to study English and this is followed by $42,30 \%$ of the students who use it less than one hour to study English, and 28,20\% of them use it for 1-2 hours a day.

As to the $4^{\text {th }}$ research question "In which way do the students use ICT to study / learn English?", the results of frequency analysis done to find out the most used strategies to improve their language skills by English prep school students are displayed in Table 4. 
Table 4. The Most used ICT Strategies to Improve English

\begin{tabular}{lcc}
\hline \multicolumn{1}{c}{ Strategies } & Frequency & $\begin{array}{c}\text { Percent } \\
\text { (\%) }\end{array}$ \\
I write blogs in English & 5 & 3.50 \\
I use my technological devices (smart phone, tablets, etc.) in English & 66 & 46.50 \\
I play computer games in English & 66 & 46.50 \\
I listen to English songs with lyrics & 100 & 70.40 \\
I listen to English songs without lyrics & 39 & 27.50 \\
I watch films / series in English with English subtitles & 104 & 73.20 \\
I watch films / series in English without subtitles & 27 & 19.00 \\
I listen to talks (e.g. Tedtalks) in English & 25 & 17.60 \\
I write emails in English & 14 & 9.90 \\
I visit English learning websites (e.g. BBC Learning English) & 28 & 19.70 \\
I search for samples of English essays & 9 & 6.30 \\
I look for English exam samples on the Internet & 15 & 10.60 \\
I listen to podcasts & 17 & 12.00 \\
I send messages in English through whatsapp & 30 & 21.10 \\
I follow English video courses & 21 & 14.80 \\
I use applications (e.g. Cambly) to practice speaking & 20 & 14.10 \\
I use online dictionaries (e.g. Cambridge, Oxford) & 55 & 38.70 \\
I read e-books in English & 26 & 18.30 \\
I read newspapers online & 14 & 9.90 \\
I listen to the news online & 9 & 6.30 \\
I search for information online to write an essay & 9 & 6.30 \\
I search for information to prepare a speech or a presentation & 27 & 19.00 \\
I listen to audio books & 57 & 9.90 \\
I use online translation programs (e.g. Google translate) & 33.10 \\
I follow/am involved in an online course/a virtual class (e.g.MOOC) & 5.50 \\
\hline Others & & 15.50 \\
\hline
\end{tabular}

Watching films / series in English with English subtitles is the most preferred strategy $(73,20 \%)$ among English prep school students. It is followed by listening to English songs with lyrics with 70, 40\%. Playing computer games in English (46,50\%) and using my technological devices (smart phone, tablets, etc.) in English (46,50\%) come at the third rank together. The top three least preferred strategies are as follows: writing blogs in English (3,50\%), following / being involved in an online course / a virtual class (3,50\%) and searching for samples of English essays (6,30\%), listening to the news online $(6,50 \%)$ and searching for information online to write an essay $(6,50 \%)$. When the 22 answers given to the other $(s)$ option were investigated, it was seen that the English prep school students stated chatting $(\mathrm{f}=9)$, playing games $(f=4)$, social media $(f=4)$, correspondence $(f=4)$ and applications $(\mathrm{f}=2)$ as the other strategies they used although some of these options (e.g. games, social media) are already among the options they were given. 
Table5. Factors preventing students from using ICT to study English

\begin{tabular}{lcc}
\hline Factors & $\bar{x}$ & sd \\
\hline Lack of interest in ICT & 2.23 & 1.07 \\
Not liking studying English & 2.61 & 1.67 \\
Not having enough proficiency in ICT & 2.22 & 1.10 \\
Not having enough English proficiency & 2.54 & 1.16 \\
Problems with the infrastructure (e.g. poor Internet) & 2.42 & 1.34 \\
Not having enough guidance and support from the teacher & 2.01 & 1.07 \\
\hline
\end{tabular}

In order to interpret the findings, since there are five categories, the rank value $(5-1=4)$ was divided into 5 and the class interval was calculated as 0,80 . According to this value, the mean scores between 1,00-1,80, 1,81-2,60, 2,61-3,40, 3,41-4,20 and 4,21-5,00 are accepted as at the level of 'Strongly agree', 'Agree', 'Neutral', 'Disagree' and 'Strongly disagree' respectively. Therefore, except for the item 'Not liking studying English' which was stated as 'Neutral', English prep school students expressed 'Agree' as their opinion for all the items. According to mean scores obtained, 'Not having enough guidance and support from the teacher' was stated as the most important factor which hinders using ICT to study English and the second most important factor was expressed as 'Not having enough proficiency in ICT'. The other factors which the students thought hindered their ICT use are 'Lack of interest in ICT', 'Problems with the infrastructure', 'Not having enough English proficiency' and 'Not liking studying English' in order of mean scores.

\section{Discussion}

In general, the $1^{\text {st }}$ research question reveals that language preparatory school students spend a lot of time on the Net, but they usually prefer to use it for their leisure time activities rather than for their academic studies. Concerning the findings of the $2^{\text {nd }}$ research question "What do they use the Internet for?", it is possible to say that the participants seem to fall in the category of collaborative or basic users of modern technologies, mostly sharing files, playing games, communicating with friends as mentioned in the studies by Luckin et al. (2009) and Kennedy et al. (2010) respectively. There are other studies which align with this finding of this current study. Corrin et al, (2010) and Shaw and Gant (2002)'s studies also reveal that young generation use the Internet for fun, socializing and getting knowledge. Likewise, Lee at el. (2014)'s research, investigating the undergraduates' patterns and perceptions of technology use in teaching and learning English, reveals that the students use more technology for their daily life activities than for academic purposes.

Except a minority of them, participants revealed that they use modern technologies to study English. As Chapelle (2009) points out that technology dramatically extends and changes the breadth and depth of exposure that learners can have with the target language and interactive events in which they have the opportunity for language focus and students have to take the advantage of this issue. Therefore, students need to better understand the advantages of using ICT so as to improve their English skills and competence. Apart from that, only 14,10\% of the students stated that they never use ICT to study English, which is quite an interesting fact in this era of advanced technology and knowing that these students are compulsory students of English who need to learn English before they continue studying at their majors. Likewise, 42,30\% of the students use it less than one hour to study English, and 28,20\% 
of them use it for 1-2 hours a day. Overall, it is possible to say that the majority of the students use ICT to study English daily; the hours spent on it is rather low though.

When considering the activities the participants choose to study English, it is possible to make the assumption that students prefer to use strategies like watching films / series in English with English subtitles, listening to English songs with lyrics and playing computer games in English which are likely to be the ones that could be done for entertainment rather than for the pure purpose of learning English such as using an online language dictionary, visiting a professional web page to learn English, etc. Students not following / being involved in an online / virtual class also is an indicator of teachers' not preferring a virtual class to support their students to promote their language skills outside the classroom.

Using modern technologies allows learners to select the learning materials they are interested in or which are suitable to their needs and these technologies are available at standalone or via the Internet at school or at home with or without teacher support (Lee, Yeung \& Ip, 2016). Yet, although the top three marked alternatives chosen by the participants are more related to having fun, they at least use some strategies related to language learning; though the variety is limited. In addition, these results show that students need guiding from their teachers about how to use different strategies more effectively; concerning the time they spent using modern technologies to study English. When concerning the role of technology in the context of education, that would not be illogical to think that teachers are required to use technology efficiently and effectively so that students' interest to boost their skills in the language learning process can be enhanced as well (Muslaini, Kristina \& Sutomo, 2019). There is no doubt that teachers are required to have knowledge about technological pedagogical content knowledge to better help the $21^{\text {st }}$ century language learners. (Teo, 2006; Ball, Thames \& Phelps, 2008).

Concerning the barriers which hinder participants from using modern technologies to study English, participants' expressing Not having enough guidance and support from the teacher' as the most important factor is striking. Language teachers and researchers using both established and emerging technological applications appear to assume that their students already have the knowledge and skills needed to turn these to their best use in language learning (Hubbard (2013). However, learners could face some challenges such as, unfamiliarity with the tools, information overload, distraction and prevailing lurking behaviors (Manca \& Ranieri, 2016). According to Winke and Goertler (2008)'s study, which was carried out with 911 basic level foreign language students at an American college, the students were not very good at using information and communication technologies to learn a foreign language in or outside the classroom although they were highly computer literate. In Lee et al. (2014)'s study, although some students thought that modern technologies made language learning easier, some of them opined that they were not feeling comfortable to use digital tools. In another study by Margaryan et al. (2011), teachers are seen as the main providers of getting ideas in terms of technology use for learning by the UK university students. This current result also shows that learners' use of ICT inside and especially outside classroom has to be guided. Therefore, teachers' technological skills are really important; they need to improve their skills for how to use computer technology and web-based English materials in their teaching practice, recognizing that technology can enhance students' self-directed learning, resulting in more positive outcomes.

\section{Conclusion}

The most noteworthy conclusions of this present study are as follows:

- English prep school students use modern technologies more for leisure time activities than academic studies. 
- Although they can benefit from using modern technologies to study English a lot, it is not included in their top-three-list.

- The students are not aware of most of the strategies they can use to study English or they simply don't prefer them.

- They need guiding to integrate ICT in their language studies.

- Teachers themselves have to have the required skills to work with modern technologies and be good role models for their students to integrate ICT more into class so that the students, too, can increase their chances of using modern technologies in language learning.

Information and communication technologies help learners expand their own communicative skills, and provide a lot of alternatives of the target language for learners. In addition, learners are able to manage their own learning at their own pace (Lai, 2013) and this can help them take more responsibilities for their own learning, promoting a more student-centered approach (Gilakjani, 2016). Yet, education policy makers, schools and education institutions have to think about how to develop these skills and teachers need to be effective users of modern technologies to integrate them into learning environments, being aware of the $21^{\text {st }}$ century learners' changing needs and attitudes in this globalized world, letting them be exposed, especially to more social learning environments where they can find immense authentic materials and more to learn a language.

This study has some limitations. First of all, the data was gathered through a questionnaire; thus, a mixed method would decrease the susceptibility of this study. Secondly, this study was carried out with a small cohort of compulsory English language students at a prep school at a state university and therefore the applicability of its findings may be limited. Yet, the findings obtained out of this study are consistent with the researches in different contexts as discussed above.

\section{Ethics Committee Approval}

The author(s) confirm(s) that the study does not need ethics committee approval according to the research integrity rules in their country (Date of Confirmation: May 26, 2020).

\section{References}

Aiken, L. R. (1997). Questionnaires and inventories: Surveying opinions and assessing personality. New York: John Wiley \& Sons, Inc.

Bailey, K. M. (2005). Practical English Language Teaching: Speaking. New York: McGraw-Hill.

Balaban Sal1, J. (2012). Verilerin Toplanması. In Ali Şimşek (Ed.). Sosyal Bilimlerde Araştırma Yöntemleri (pp. 135-154), Eskişehir: AÖF Yayınları.

Ball, D. L. , Thames, M. H. \& Phelps, G. (2008). Content knowledge for teaching: What makes it special? Journal of Teacher Education. 59(5), 389-407.

Banditvilai, B. (2016 ), Enhancing Students' Language Skills through Blended Learning. Electronic Journal of e-Learning, 14(3), 220-229.

Bellhouse, D.R. (2014). Systematic Sampling Methods. In Wiley Stats Ref: Statistics Reference Online; New York, NY, USA; John Wiley \& Sons, 
Ben-David Kolikant, Y. (2009). Digital students in a book-oriented school: Students' perceptions of school and the usability of digital technology in schools. Educational Technology \& Society, 12(2), 131-143.

Ben-David Kolikant, Y. (2010). Digital natives, better learners? Students' beliefs about how the Internet influenced their ability to learn. Computers in Human Behavior, 26(6), 1384-1391.

Brown, D \& Warschuer, M. (2006) From the University to the Elementary Classroom: Students' Experiences in Learning to Integrate Technology in Instruction. Journal of Technology and Education, 14(3), 599-621.

Chapelle, C. A. (2009). The Relationship between Second Language Acquisitions Theory and Computer-Assisted Language Learning. The Modern Language Journal, 93, 731-753.

Corrin, L., Lockyer, L. \& Bennett, S. (2010). Technological diversity: an investigation of students' technology use in everyday life and academic study. Learning, Media, and Technology, 35(4), 387401, DOI: $10.1080 / 17439884.2010 .531024$

Crook, C. \& Harrison, C. (2008). Web 2.0 Technologies for Learning at Key Stages 3 and 4: Summary report. Coventry, UK: Becta report.

Elmas, R. \& Geban, Ö. (2012). Web 2.0 tools for $21^{\text {st }}$ century teachers. International Online Journal of Educational Sciences, 4(1), 243-254.

Gilakjani, A. P. (2016). The Relationship between Information and Communication Technologies and Foreign Language Teaching and Learning. Modern Journal of Language Teaching Methods (MJLTM), 6(4), 67-77.

Harmer, J. (2007). The Practice of English Language Teaching ( $4^{\text {th }}$ ed.). Pearson; Longman.

Helsper, E. J., Dutton, W. \& Gerber, M. (2009). To Be a Network Society: A Cross-National Perspective on the Internet in Britain. Oxford Internet Institute, Research Report No. 17.

Hubbard, P. (2013). Making a Case for Learner Training in Technology Enhanced Language Learning Environments. CALICO Journal, 30(2), 163-178.

Kennedy, G., Judd, T., Dalgarnot, B. \& Waycott, J. (2010). Beyond natives and immigrants: exploring types of net generations students. Journal of Computer Assisted Learning, 26 (5), 332-343.

Kvavik, R. (2005). Convenience, communications and control: How students use technology. In, D. G. Oblinger \& J. L. Oblinger (Eds.) Educating the net generation, an educause e-book publication (pp.7.1-7.20).

Lai, C. (2013). A Framework for Developing Self-Directed Technology Use for Language Learning. Language Learning \& Technology, 17(2), 100-122.

Lee, C., Yeung, A. S. \& Ip, T. (2016). Use of computer technology for English language learning: do learning styles, gender, and age matter? Computer Assisted Language Learning, 29(5), 1035-1051.

Lee, K. W., Thang, S. M., Tan, C. K., Ng, S. I., Yoon, S. J., Chua, Y. W.,and Shelly Shirlenna, N. (2014). Investigating the ICT needs of 'Digital Natives' in the learning of English in a public university in East Malaysia. Procedia-Social and Behavioral Sciences, 118, 242-250.

Luckin, R., Clark, W., Graber, R., Logan, K., Mee, A. \& Oliver, M. (2009). Do Web 2.0 tools really open the door to learning? Practices, perceptions and profiles of 11-16-year-old students. Learning, Media and Technology, 34(2), 87-104. DOI: 10.1080/17439880902921949 
Lunenburg, F. C. \& Ornstein, A.C. (2004). Educational Administration: Concepts and Practices. (4 ${ }^{\text {th }}$ ed.), Wadsworth, USA.

Manca, S. \& Ranieri, M. (2016). Facebook and the others. Potentials and obstacles of Social Media for teaching in higher education. Computers and Education, 95, 216-230.

Margaryan, A., Littlejohn, A. \& Vojt, G. (2011). Are digital natives a myth or reality? University students' use of digital technologies. Computers \& Education, 56(2), 429-440.

Misir, H. (2018). Digital literacies and interactive multimedia-enhanced tools for language teaching and learning. International Online Journal of Education and Teaching (IOJET), 5(3), 514-523.

Muslaini, F., Kristina, D. \& Sutomo, N. (2019). A Preliminary Study of EFL Reading Android Application Development. International Online Journal of Education and Teaching (IOJET), 6(1), 151-168.

Nachoua, H. (2012). Computer-Assisted Language Learning for Improving Students' Listening Skill. Social and behavioral Sciences, 69, 1150-1159.

Nor, N. M. \& Rashid, R. A. (2018). A review of theoretical perspectives on language learning and acquisition. Journal of Social Sciences, 39, 161-167.

Prensky, M. (2001). Digital natives, digital immigrants. On the Horizon, 9(5), 1-6.

Rahamat, R. B., Shah, P. M., Din, R. B. \& Aziz, J. B. A. (2017). Students' Readiness and Perceptions towards Using Mobile Technologies for Learning the English Language Literature. The English Teacher, XL, 69-84.

Sarıçoban, A., Tosuncuoğlu, İ \& Kırmızı, Ö. (2019). A technological pedagogical content knowledge (TPACK) assessment of pre-service EFL teachers learning to teach English as a foreign language, Journal of Language and Linguistic Studies, 15(3), 1122-1138. Doi: 10.17263/jlls.631552

Shaw, L. H. \& Gant, L. M. (2002). Users divided? Exploring the gender gap in internet use. Cyber Psychology \& Behavior, 5(6), 517-527.

Shishkovskaya, J., Bakalo, D. \& Grigoryev, A. (2015). EFL Teaching in the E-Learning Environment: Updated Principles and Methods. Social and Behavioral Science,s 206, 99-204.

Tapscott, D. (1998). Growing up digital: The rise of the net generation. New York: McGraw-Hill.

Tapscott, D. (1999). Educating the Net Generation. Educational Leadership, 56(5), 6-11.

Tay, L. Y., Lim, S. K., Lim, C. P. \& Koh, J. H. L. (2012). Pedagogical approaches for ICT integration into primary school English and mathematics: A Singapore case study. Australasian Journal of Education Technology, 28(4), 740-754.

Teo, T. (2006). Attitudes toward computers: A study of post-secondary students in Singapore. Interactive Learning Environments, 14(1), 17-24.

Wang, B. T., Teng, C. W. \& Chen, H. T. (2015). Using iPad to Facilitate English Vocabulary Learning. International Journal of Information and Education Technology, 5(2), 100-104.

Winke, P. \& Goertler, S. (2008). Did we forget someone? Students' computer access and literacy for CALL. CALICO Journal, 25(3), 482-509.

Zainuddin, Z. \& Perera, C. J.(2018). Supporting students' self-directed learning in the flipped classroom through the LMS TES BlendSpace. On the Horizon, 26(4), 281-290. 


\section{İngilizce hazırlık sınıfı öğrencilerinin yabancı dil öğrenmede modern teknolojileri kullanımı}

\section{Öz}

Yabancı dil öğrencilerine iletişim yeterliği kazandırabilmek için yaratıcı ve etkili öğrenme ortamları sağlamak büyük önem taşımaktadır. Bu bağlamda, teknolojinin yabancı dil öğreniminde kullanımı daha önemli bir hal almıştır. Bunun temel nedeni, bilgisayar ve diğer iletişim teknolojilerinin, yabancı dil öğrenenlerin, kendilerini hedef dile maruz bırakmaları ve kendilerine daha fazla doğal öğrenme ortamı sağlamasında oldukça önemli olmasından kaynaklanmaktadır. Teknoloji günümüz üniversite öğrencilerinin hayatında önemli bir yer kaplamaktadır ve bir kısmı da yabancı dil becerilerini geliştirmek için teknolojiden faydalanmaktadır. Ancak, yabancı dil öğrenme ve öğretme metot ve tekniklerinin, günümüz dijital okuryazarların isteklerine ne kadar cevap verebildiği ve öğrencilerin bu metot ve teknikleri ne düzeyde kullandığı tartışma konusudur ve Türk yükseköğretiminde bu konuda yeterli çalışma yapılmadığı görülmüştür. Bu çalışmanın amacı, öğrencilerin yabancı dil öğreniminde teknolojiden nasıl faydalandıkları ve hangi stratejileri kullandıklarını ortaya çıkarmaktır. $\mathrm{Bu}$ amaca uygun olarak bir devlet üniversitesinin İngilizce hazırlık sınıflarında okuyan öğrencilere küçük ölçekli bir anket uygulanmıştır. Sonuçlara göre, öğrencilerin yabancı dil öğreniminde teknoloji kullanma konusunda çok istekli olmadıkları ve yaygın olarak kullanılan birkaç strateji dışında, pek çok öğrenme stratejisini kullanmadıkları ortaya çıkmıştır. Öğrenciler bu konuda desteğe ihtiyaç duyduklarını belirtmişlerdir ve bu sonuca dayanarak, yabancı dil öğretmenlerinin de modern teknolojiyi sınıf ortamına aktarmak ve öğrencilere yol göstermek konusunda yeterli becerilere sahip olmaları gerektiği söylenebilir.

Anahtar kelimeler: teknoloji kullanımı; dil becerilerinin gelişimi; dil öğrenme ortamları

\section{AUTHOR BIODATA}

Başak Ercan is an instructor of English at the School of Foreign Languages at Akdeniz University. She has a BA in ELT from Middle East Technical University and an MA in Education Management and Supervision from Akdeniz University. 